\title{
The Theoretical Basis of Judicial Intervention to Disagreements among Shareholders in French Law
}

\author{
Rongxin Zeng and Jia Li
}

\begin{abstract}
In French law, the theoretical basis of the judicial intervention to the disagreement among shareholders has undergone an important evolution: the modern tendency is to abandon the traditional theories of abuse of power and abuse of right, and adopt the theory of duty of good faith of shareholders. The present article is an intensive study of this evolution. It seeks to analyze the defects of the traditional theories, and point out the advantages of the new theory and its revelatory effect.
\end{abstract}

Index Terms-Abuse of power, abuse of right, duty of good faith, disagreement.

\section{INTRODUCTION}

The disagreement among shareholders is actually an abuse of their voting rights. Some shareholders pursue their personal interests in prejudice of the general interest of the company. The disagreement may probably lead to the impasse of the company, and finally cause finally prejudice to the interests of shareholders themselves, the company and even public wealth. The resolution of the difficult situation necessitates the judicial intervention. But it is necessary to ask : what is the theoretical basis of the judicial intervention to such a situation is. Looking back at the On this point, there is an evolution in French legal history, the traditional doctrine and jurisprudence preferred the theories of abuse of power or abuse of rights, which are gradually considered as untenable; , while the modern tendency is to apply the theory of the duty of good faith. This research aims to analyze the defects of the traditional theories, and point out the advantages of the new theory and its revelation effect.

\section{Theories of Abuse of Power AND Abuse of Right: THEORIES UNTENABLE}

\section{A. The Theory of Abuse of Power}

The abuse of power is a concept of administrative law for controlling administrative powers. It is defined as "the situation where an administrative official exercise his jurisdiction for purposes other than the general interest, or at least for a different purpose of that for which it was conferred." The most original idea for justifying the judicial protection of minority shareholders is the theory which compares the statutory powers with the administrative powers. The main pioneer of this theory is Mr. Josserand. [1]

Mr. Josserand pointed out that the reprehensible use of

Manuscript received September 26, 2012; revised November 20, 2012.

Rongxin Zeng is with the School of Law, Jiangxi University of Finance and Economics, Nanchang, 330032 China (e-mail: zrx0501@gmail.com).

$\mathrm{Jia} \mathrm{Li} \mathrm{is} \mathrm{with} \mathrm{Faculty} \mathrm{of} \mathrm{Foreign} \mathrm{Studies,} \mathrm{Jiangxi} \mathrm{University} \mathrm{of} \mathrm{Science}$ and Technology, Ganzhou, 341000 China (e-mail: Lijia-lyn@hotmail.com). shareholders voting rights was a form of abuse of power in the sense of administrative law. According to the theory which earned a wide support at that time, the majority shareholders have powers only when they exercise them for the interests of the company. In other words, the power of majority shareholders can only find its legitimacy in accordance with interests of the company. [2] In situation where the interests of the company were not satisfied, the majority shareholders divert the purpose of their powers, which can precisely be considered as an abuse of power. [3]

Then, there remains a problem that whether this theory should be applied to the situation where the minority shareholders abuse their power or not.

Some scholars consider that the minority shareholders do not have the opportunity to make their views prevail over majorities, while the power implies that the holder can enforce his position. Therefore, the minorities who block illegitimately the adoption of a decision can not commit abuse of power. However, others believe that the abuse of minority occurs only for important changes fixed by the statute of the company. In these situations, the minority shareholders have a blocking minority. By abusing their right to vote, they prevent the adoption of a decision desired by the company, impose their views on the majorities and the company and turn away from its purpose by ignoring the interests of the company. In this sense, the minorities diverted their powers in the same way as the majority shareholders do. If these arguments are justified, it must be admitted that the reprehensible use of shareholders voting rights constitutes an abuse of power.

In fact, as Mr. Neuburger points out that "there is no legal text supporting this theory", instead there is just an analogue but non-assimilation between the abuse of voting rights and abuse of power. [4] The theory of the abuse of power just represents a "simple argument by analogy" in this situation. [5] Officials in administrative law have to perform their functions and exercise their powers for the sole purpose that the law has assigned to them. In other words, administrative officials should never take into account of their personal interests including interests that are not contrary to the public interest. However, shareholders may vote for their own interests, provided that they would not be contrary to interests of the company. Certainly, these votes are not only components of the social will, but also they may enable shareholders to defend theirs own interests in the company. As a consequence, shareholders, not like administrative officials or officeholders, can and should take into account of theirs own interests when they exercise their voting rights. [6] As Professor Schmidt says, "the majority shareholders have the power to satisfy not only the interests of others, but also their own". [7] Moreover, there are few cases expressly refers 
to the theory of abuse of power.

\section{B. The Theory of Abuse of Right}

Besides the theory of abuse of power, the French jurisprudence and doctrine also refers to the theory of abuse of right for getting a rational theoretical basis of judicial intervention to disagreements between shareholders.

A former belief used to be that a rights holder was completely free to exercise his rights. Gradually, the jurisprudence, with support of the majority of the doctrine, [8] declared that the holder of rights can not abuse his right. [9] Mr. Ripert, a famous French jurist, accepts the theory of abuse of right, but he insists that the theory should be applied in a restrictive sense. [10] According to him, the abuse of right does not lie in injury to others, but the intent to harm or awareness of harm to others at least. Moreover, some modern scholars consider that the fault committed in the exercise of a right is the most significant symbol of the abuse of right. [11]

In other words, the theory of abuse of rights presupposes at least one of the two elements: the malice of the holder of rights, or the fault committed in the exercise of right.

The problem remains here is whether these concepts should be adapted to the situation of the exercise of voting rights in the company. Does the vote of shareholders "contrary to the interests of the company and for the sole purpose of promoting their own interests at the expense of all other shareholders" constitute an abuse of right?

On the one hand, neither the abuse of majority nor the abuse of minority necessarily implies the malice of the stakeholders.

On the other hand, the reprehensible vote issued by shareholders does not constitute a fault in the exercise of right for the following reasons.

First, for determining what a reprehensible vote is, one of the primary matters is to determine what an appropriate vote is. [12] Once we know what is right, we know what is wrong. That assessment is indeed difficult because there exists no expressly evaluation criterion. One criterion may be as simple as the following: the shareholders should approve projects presented by the executives who are responsible for the day-to-day operations of the company. But this criterion is so arbitrary that it would lead to denying the free voting principle of shareholders.

Second, as far as civil liability is concerned, the fault could be found in two forms, i.e. intention or negligence. The fault committed with intention may be reprehensible in companies. But the fault negligently committed is very difficult to be condemned, [13] unless judges are entitled to take the place of shareholders to make decisions for the company which could not be grounded in both theory and practice.

At last, the key problem of the controversy between the theory of abuse of power and the theory of abuse of rights is indeed the legal nature of the right to vote of shareholders. Whether the right to vote of shareholders is a power or a right of shareholders?

Viewing from one aspect, the right to vote is given to shareholders in exchange for their investments to the company, so that the proper interest and right of shareholders are concerned. However, it is necessary to ask whether the right to vote only affects the personal interest of the shareholders who exercises it. If so, it is convictive that the right to vote is a personal prerogative of shareholders.

Unfortunately, this is not the pure reality. Besides personal interests of the shareholders who exercise it, the right to vote necessarily affects the fortunes of the company and other shareholders. Therefore, some scholars stated that the vote was a performance of power for interests of the company.

Consequently, it can be summarized that the right to vote is at once a protection to personal interests of the shareholders who exercise it and a method of management of the company. [14] In other words, the right to vote is granted not only for personal interests of shareholders who exercise it, but also for the general interest of the company. As noted by the French Supreme Court, [15] "to attend and to vote at general shareholders meeting constitute at once essential prerogatives of shareholders and fulfillment of obligations incurred by themselves to the company due to their titles of shareholders."

Therefore, neither on the basis of abuse of power, nor on the basis of abuse of rights, can the judicial intervention for punishing the votes which exercised "contrary to the general interest of the company and for the sole purpose of promoting the personal interests of the shareholders who exercise it at the expense of interests of all other shareholders" be convincing. Both of the two theories are pretty feeble.

\section{THEORY OF DUTY OF GOOD FAITH: THEORY PROPOSED}

Even if the institutional dimension of company can not be ignored, the company remains a contract: it arises from a contract, and it remains a contract, especially in terms of relations between shareholders. However, article 1134, paragraph 3 of the Civil Code requires that contracts should be executed "in good faith." Besides, it seems that the French Jurisprudence attaches more attention and gives greater importance to the principle of good faith. In fact, because the execution of a contract in good faith is not strictly an obligation with a perfect determinacy and subject to compulsory execution in all the cases, [16] the requirement of executing a contract in good faith is more like a duty and a general precept that impose an imperative of loyalty to contractual parties during the term of the contract rather than a legal obligation in nature. Similarly, the obligations of loyalty and information between contractors today relate more positively to the duty of good faith.[17] On the role of good faith in commercial law, company officers has also the obligation of loyalty. [18]

Where upon we must wonder whether the vote of shareholders "contrary to the interests of the company and for the sole purpose of promoting their own interests at the expense of all other shareholders" constitute a violation of the general duty of good faith. Before considering the attitude of jurisprudence, the doctrinal trend on this problem should be examined firstly.

\section{A. The Reference to the Doctrine of Duty of Good Faith in} Theory

As mentioned before, the right to vote is granted to the shareholders by the statute of the company in exchange for their investment to the company. After the conclusion of contract of company and the accomplishment of their obligation to subscribe to shares, the investors will be granted 
the title of shareholders. No matter whether right to vote is a right or a power of shareholders, it is an privilege attached to the title of shareholders determined by statute of the company. In this sense, it is rooted in contract of the company and therefore becomes a contractual right.

The abuse of a contractual right is sanctioned on the theoretical ground of duty of good faith. Judges intend to punish disloyal behavior during the exercise of conventional rights. Abuse of right can be considered as the exercise of a right in bad faith which can be defined as a conscience of the prejudice to the other party of the contract. This point of view has been accepted by several cases. [19] Thus, if we consider the right to vote of shareholders as a contractual right, the abuse can be defined as an exercise of the right in bad faith. As stated earlier, the reprehensible vote means not necessarily that the voter is malicious, but is conscious of the harm to other shareholders, which is precisely the definition of bad faith.

Especially, the abuse of voting rights is traditionally analyzed as a failure to affectio societatis [20], a Latin legal terminology, which requires that a company should reflect the convergence of different shareholders' interests. It means that every shareholder must fulfill their own obligations, conduct themselves as a real "shareholder", and subordinate their personal interests to the general interest of the company.

However, it is unconceivable to apply the doctrine of affectio societatis without the support of the theory of duty of good faith in the contract of the company [21] just as Mr. Treilhard said, "Contract is natural law. It forms and is governed only by the rules of this law, it should be based on good faith. Good faith is necessary for all contracts, especially for contract of the company......" [22] The disappearance of affectio societatis constitutes a reprehensible exercise of voting right, and therefore can be construed as a breach of the requirement of good faith in contract.

Scholars who are interested in the theory of duty of good faith in the field of company law emphasized that this theory required shareholders to seek their personal interests through the pursuit of the company's general interest. In other words, the execution of company's contract in good faith requires shareholders to give company's interest priority over personal interests, in case of conflict between them.[23] If shareholders give priority to their personal interests, they will execute the company's contract in bad faith.

Therefore, the duty of good faith shall govern the relations among shareholders. In support of this argument, it is required that the minority shareholders must accept the majority decisions, provided that they have been made for the prosperity of the company. Once the decision is made for pursuing the general interest of the company, minority shareholders has the obligation to comply with it. Otherwise, they fail to fulfill in good faith their obligations. This is exactly the definition of abuse de minority, isn't it?

Qualifying the reprehensible exercise of voting rights of shareholders as the violation of the duty of good faith is a judicious option because this is probably the only doctrine who takes into account both the subordination of shareholders' personal interests to the general interest of the company, and contractual nature of the company.

\section{B. The Favorable Attitude of the French Court}

For a long time, jurisprudence has implicitly accepted that shareholders, no matter majorities or minorities, all have the duty of good faith to execute the company's contract. [24] However, this situation has been changed since the judgment was rendered on $27^{\text {th }}$ February 1996 [25] by the Commercial Chamber of the French Supreme Court, in which the judges expressly issued the judgment on the "theory of duty of good faith that is imposed to the executives as well as all shareholders of the company."

In this case, we must admit that the majority shareholders were not specifically mentioned in the judgment. However, it is clear that the French Supreme Court punished all persons of the company who would take advantages of their position in the company for selfish purpose, no matter they are shareholders or executives.. Moreover, most executives generally come from the majority shareholders in practice, so the duty of good faith is the essence of the company's contract. [26] Although all shareholders can not be exempted from this duty, this theory has a universal significance for the whole company law.

In a judgment on $10^{\text {th }}$ July 2007, the French Supreme Court emphasized again the duty of shareholders to execute in good faith the company's statute, and applied some adverse consequences in case of "disloyal execution". In this case, the Court overturned the decision in question for breach of paragraphs 1 and 3 of article 1134 of the Civil Code. The judges held that "if the rule that contracts must be performed in good faith allows the judge to punish disloyal execution of contractual rights, it does not allow him to affect the substance of the legal rights and obligations agreed by the contractual parties." In case of disagreement among shareholders, it is necessary to apply the principle of non-interference in the company of the judge since the Supreme Court held that "the court could not substitute for company organizations legally competent ..." [27]

In conclusion, the reference to the theory of duty of good faith marks a return to the traditional approach of company law is and also a contractual renewal in this branch of law. This reference to the contractual characteristic of the company is always useful for analyzing the constitutive requirements of disagreement among shareholders and its corrective measures.

\section{REFERENCES}

[1] Charles Louis Montesquieu, The Spirit of the Laws, Seconde version, 1939, pp.192.

[2] C. Ruellan, The majority rule in commercial companies, Doctoral thesis of Paris II University (France), 1997, no. 540.

[3] R. Kaddouch, The Voting Rights of Shareholders, Doctoral thesis of Aix-Marseille III University (France), 2001.

[4] P. Coppens, The abuse of majority in the Limited Liability Company, Gembloux Presse(Belgique), 1947, pp.77.

[5] P. Coppens, The abuse of majority in the Limited Liability Company, Gembloux Presse (Belgium), 1947, pp.78.

[6] R. Kaddouch, "The Voting Rights of Shareholders," Doctoral thesis of Aix-Marseille III University (France), 2001.

[7] D. Schmidt, Conflicts of interests in the Limited Liability Company, JOLY Press (France), 2004.

[8] M. Ripert, "The moral rule in Naturalis obligatio," 1935, pp. 89.

[9] M. Planiol, "Elementary Treatise," 1943, pp. 367.

[10] G. Ripert, The moral rule in Naturalis obligatio, LGDJ Press (France), 1949, pp. 90.

[11] L. Cadiet and Ph. L. Tourneau, Civil Liability law, Dalloz Press, 1996, pp. 3154,1999 , no. 711 . 
[12] J. Hame, The protection of minorities shareholders in the Limited Liability Company, RID comp., 1951, p. 677.

[13] D. Schmidt, The rights of minorities shareholders in the Limited Liability Company, JOLY Press, pp. 239.

[14] P. Coppens, The abuse of majority in the Limited Liability Company, Gembloux Presse (Belgium), 1947, pp. 83.

[15] N. J. Noirel, "Important cases of commercial jurisprudence," pp. 64.

[16] P. Delebecque, "Clauses for alleviating the obligations in contract, Doctoral thesis of Aix University (France)," 1981, no. 360.

[17] "Supreme Court," Civil chamber, Feb. 28, 1989, D.1989, IR, 96.

[18] "Supreme Court," Commercial chamber, Feb.27, 1996, JCP 1996, II, 22665 , note Ghestin.

[19] "Supreme Court," plenary session, Dec. 1st. 1995, JCP 1996 II no. 22565, concl. M. Jeol, note J. GHESTIN, RTD civ. 1996, pp. 153, Note J. Mestre - Rappr.; Supreme Court, civil chamber, Feb. 1st, 1985, Bull. I no. 54; RTD civ. 1986 p. 105, obs. J. Mestre; Supreme Court, commercial chamber, May 31, 1994, Bull. IV no. 194.

[20] D. Schmidt, The rights of minority's shareholders in the Limited Liability Company, JOLY Press, 1970, no. 239.

[21] A. Viandier, The concept of shareholders, Bibl. Private Law, vol. 156, LGDJ Press, 1978. no. 7.

[22] Treilhard, The discussions of the legislative body under the Civil Code relating to the company contract, 1955 , pp. 1.

[23] R. David, The protection of minorities shareholders in the Limited Liability Company, Doctoral thesis of Paris University (France), 1928, no. 52.

[24] CA Paris, Feb.16, 1933 and April 13, 1934, D.P. 1936 II p. 121, note P. Pic, which refers to the obligation of majority shareholders to govern by the principle of good faith.

[25] JCP 1996, II no. 22665, note J. Ghestin; JCP Press. E 1996 no. 838, note D. Schmidt and N. Dion.

[26] J. Ghestin, JCP 1996, no. 22665.

[27] "Supreme Court," commercial chamber, March 9, 1993, aff.Flandin: D 1993, 363 notes Y. Guyon.

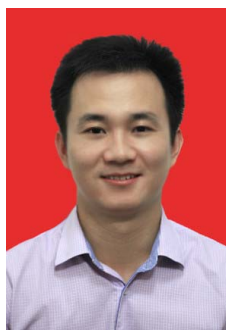

Rongxin Zeng was born in Ganzhou City of Jiangxi Province in China on May 1, 1983. He received a Bachelor's degree in Economics from Beijing Information Technology Institute, China, a Master's degree in law from Shanghai University, China, and a Master's degree and a juris doctoral degree in law from University Paris 2, France.

He works as a lecturer of law in Jiangxi University of Finance and Economics in Nanchang city in China. His main publications are as follows:

Real estate operations and notary system at civil law legal system, US-China law Review, 2012, NO. 12.
The communication of legal information and socialist legal construction, social scientist, 2012, NO. 12.

A comparative study of the pledge of share rights between France and China, in ICEEM 2nd International Conference on Economic, Education and Management ), June 1-2, Shanghai, China.

A comparative study of security interests in French Law and in Chinese law, Doctoral thesis of Paris II University (France).

A comparative study of security interests in French Law and in Chinese law, in Revue international de droit comparé, 2011, NO. 2.

His main research interest is private law.

Dr. Zeng is a member of the China Law society, and the Fondation pour le droit continental. His doctoral thesis was awarded the first prize of the Excellent Doctorial Thesis prizes for the year 2011 of the Fondation pour le droit continental.

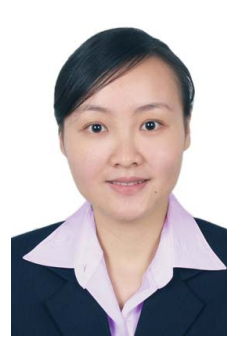

Li Jia was born in Ganzhou City of Jiangxi Province in China on December 5th, 1984. She got her Master's degree in arts in teaching English to speakers of other languages from Canberra University of Australia in 2009. She also got postgraduate diploma in applied linguistics in Nanyang Technological University of Singapore in 2012.

She used to work in Gannan Medical University (GMU) in Ganzhou City of Jiangxi Province in China teaching foreign students Chinese and Chinese students English. She also worked there as a member in International Education College being responsible for creating cooperation between GMU and overseas universities. Now, she is working in Faculty of Foreign Studies of Jiangxi University of Science and Technology also in Ganzhou. She works as a lecture teaching Chinese College students English courses. She published several articles like Teaching Guided By the Cognitive Principle and Comparison between Input Hypothesis and Interaction Hypothesis publishing in journal of Overseas English in 2010 and 2012, How Can Self-access Centers in China Better Develop Students' Learner Autonomy will be published in journal of Sino-US English Teaching (USA) in the 11th issue of 2012. Miss. Li's will continue her research interests in Second Language Acquisition and English Teaching Methods. She will also develop research interests in English for special purpose like English in Law.

Miss. Li is now a member in Singapore Association of Applied Linguistics (SAAL). She actively participated in the activities in SAAL. Her publications can provide some useful information in second language teaching and learning. 